\title{
Association of Rhinoceros Beetle (Coleoptera: Scarabaeidae) with Three Agave Plant Species
}

\author{
Sujak $^{1 *}$, Dwi Adi Sunarto ${ }^{1}$, Nurindah $^{1}$ \\ ${ }^{I}$ Indonesian Sweeteners and Fiber Crops Research Institute, Malang, East Java 65152, Indonesia \\ "Corresponding author.Email: sujakbalittas@gmail.com
}

\begin{abstract}
Rhinoceros beetle (Coleoptera: Scarabaeidae) is known as a phytophagous insect found associating with Agave spp. and has the potential to become a pest in crop cultivation. Agave is a fiber-producing plant utilized in natural fiber-based industries. This research was carried out with the aim to determine the effect of rhinoceros beetle infestation associated with three species of agave plants which are accessions from agave germplasm collection of ISFCRI. The study was conducted at Karangploso Research Station, Malang, Indonesia. Observations were made in 2017 on three species of agave plants, namely Agave angustifolia (4 accessions), A. cantala (14 accessions), and A. sisalana (7 accessions). Rhinoceros beetle infested the plant by boring into young leaves that are still rolled up and if it reached the growing point, it could cause the plant to die. Plant damage that occurs in all three agave plant species indicates that rhinoceros beetle infestation occurs in all three species Agave. The beetle preference for A. angustifolia is relatively high compared to the other two species. The high preference for A. angustifolia is presumably due to the high sugar content in plant stems (pina), which is the consumption target of rhinoceros beetle in infesting agave plantations.
\end{abstract}

Keywords: Agave angustifolia, Agave cantala, Agave sisalana, Rhinoceros beetle

\section{INTRODUCTION}

Agave (Family Agavaceae) is a genus of $200-300$ species that exist in the world. Agave plants have been used as a source of natural fiber, food, and beverages [13]. Recent studies show that agave has the potential to serve as a source of active ingredients for pharmaceuticals, prebiotics, natural sweeteners, and biofuels [2, 4-7]. Agave fibers have certain advantages to synthetic fibers, for example, they have lower density and cost, additionally they are also biodegradable. Agave spp. is reportedly of Mexican origin, and can live on dry land conditions. Agave can reduce total water consumption and transpiration, because $\mathrm{CO}_{2}$ absorption occurs during the night, and stomata opens to liberate less amounts of water as is normal in the day, so this plant species is very efficient in using water [8].

Agave spp. is cultivated in Indonesia, especially in arid climates. Agave cantala is widely grown in Madura, the fiber is used for tobacco ropes, while A. sisalana is widely cultivated in Nusa Tenggara, the fiber is used for industries based on natural fibers. Agave angustifolia is cultivated not for fiber utilization, but this plant has high economic value in Mexico as an ingredient in making "bacanora", an ancient traditional drink similar to tequila, but with a different flavor.

Indonesian Sweetener and Fiber Crops Research Institute (ISFCRI)/ Balai Penelitian Tanaman Pemanis dan Serat (Balittas) manages 26 germplasm accessions of Agave spp. which consists of 3 species, namely $A$. angustifolia, A. cantala, and A. sisalana. Management of agave accessions through germplasm conservation activities. In the management of Agave spp. germplasms, the data on insects associated with agave plants is one of the parameters observed. This data is useful for information about genetic sources that will be used in the research and development of this commodity.

Agave spp. is a plant that is rich in nutrients as a source of insect feed [9]. One of the phytophagous insects found associated with Agave spp. in ISFCRI/ Balittas germplasm collection is rhinoceros beetles. Xyloryctes corniger Bates and $X$. thestalus Bates are rhinoceros beetles reportedly associated with A. tequilana [10-12] whereas Oryctes rhinoceros was reported as a minor pest of A. sisalana [13]. O. rhinoceros is a species whose distribution is found throughout the Asian and Western Pacific regions [14]. Kalshoven [15] reported that agave is one of the host plant of $O$. rhinoceros in Indonesia.

Rhinoceros beetle infestation on Agave spp. in Indonesia has the potential to cause weight loss of dry fiber up to $23.8 \%$ and fiber yield up to $17.4 \%$ [16]. Study of interactions between Agave spp. as a host of rhinoceros beetles in Indonesia has not been done intensively. Therefore, this study aims to evaluate rhinoceros beetle infestation on three Agave species in the Field of ISFCRI/ Balittas Germplasm Collection. The information obtained can be used as a basis for consideration in developing superior agave varieties related to their resistance to rhinoceros beetles. 


\subsection{Materials and Methods}

Observations on infestation and damage of agave leaves by rhinoceros beetles were carried out at Karangploso Research Station (7³9'43”S, 114 ${ }^{\circ} 121^{\prime} E$; elevation 515 m.asl), from November 2016-January 2017. Observations were made on 26 accessions from three species of Balittas agave germplasm collection, namely $A$. angustifolia (5 accessions), A. cantala (13 accessions), and A. sisalana (7 accessions) age 6 years. The accession numbers for each Agave species used in this study are presented in Table 1.

Table 1 Germplasm accessions of Agave spp. used in the observations of rhinoceros beetles infestation in Karangploso, Malang

\begin{tabular}{|l|c|c|c|}
\hline A.angustifolia & A. sisalana & \multicolumn{2}{|c|}{ A. cantala } \\
\hline Balittas 1 & Balittas 10 & Balittas 2 & Balittas 18 \\
\hline Balittas 4 & Balittas 12 & Balittas 3 & Balittas 19 \\
\hline Balittas 5 & Balittas 13 & Balittas 6 & Balittas 21 \\
\hline Balittas 9 & Balittas 14 & Balittas 7 & Balittas 22 \\
\hline Balittas 17 & Balittas 16 & Balittas 8 & Balittas 25 \\
\hline & Balittas 23 & Balittas 11 & Balittas 26 \\
\hline & Balittas 24 & Balittas 15 & \\
\hline $\begin{array}{c}\mathrm{n}=5 \\
\text { accessions }\end{array}$ & $\begin{array}{c}\mathrm{n}=7 \\
\text { accessions }\end{array}$ & $\mathrm{n}=13$ accessions \\
\hline
\end{tabular}

Observations of leaf damage in each accession of three Agave species were carried out on 6 plants. Observations were made by counting the healthy leaves and infested leaves that showed symptoms had been consumed by rhinoceros beetles. Symptoms of leaf damage by rhinoceros beetle are the presence of bite holes with a diameter of 2-6 cm (Figure 1). The intensity of the rhinoceros beetle infestation was calculated based on the percentage of damaged leaves out of the total number of leaves on the sample plant, while the area of the beetle infestation was calculated based on the percentage of the number of plants infested against the total number of sample plants.

Identification of rhinoceros Beetles infesting agave accessions was done by comparing morphological characters of Xyloryctes and Oryctes, a method developed by Royals et al. [17].

\subsection{Our Contribution}

This study reports rhinoceros beetle infestation in Agave spp. with different levels of infestation between Agave species and clones. The difference is due to differences in the nutritional content of the leaves of Agave spp. which influences the preferences of the beetles in infesting the three Agave species. The results of this study can be used as a basis for the development of breeding a new superior variety that has a high level of resistance to the rhinoceros beetle infestation by selecting clones with low infestation rates as its parents.

\subsection{Paper Structure}

The rest of the paper is organized as follows. Section 2 is the identification of species that infest A. sisalana, $A$. cantala, and A. anguistifolia. Section 3 presents the level of infestation of rhinoceros beetles in each Agave spp. species, and also the level of infestation in each clone. Section 4 discusses the results of the data obtained related to information about the nutritional content of each accession, also the possibility of toxic compounds that affect the preferences of rhinoceros beetle to each accession and Agave species. Section 5 concludes the discussion and presents suggestions for further research.
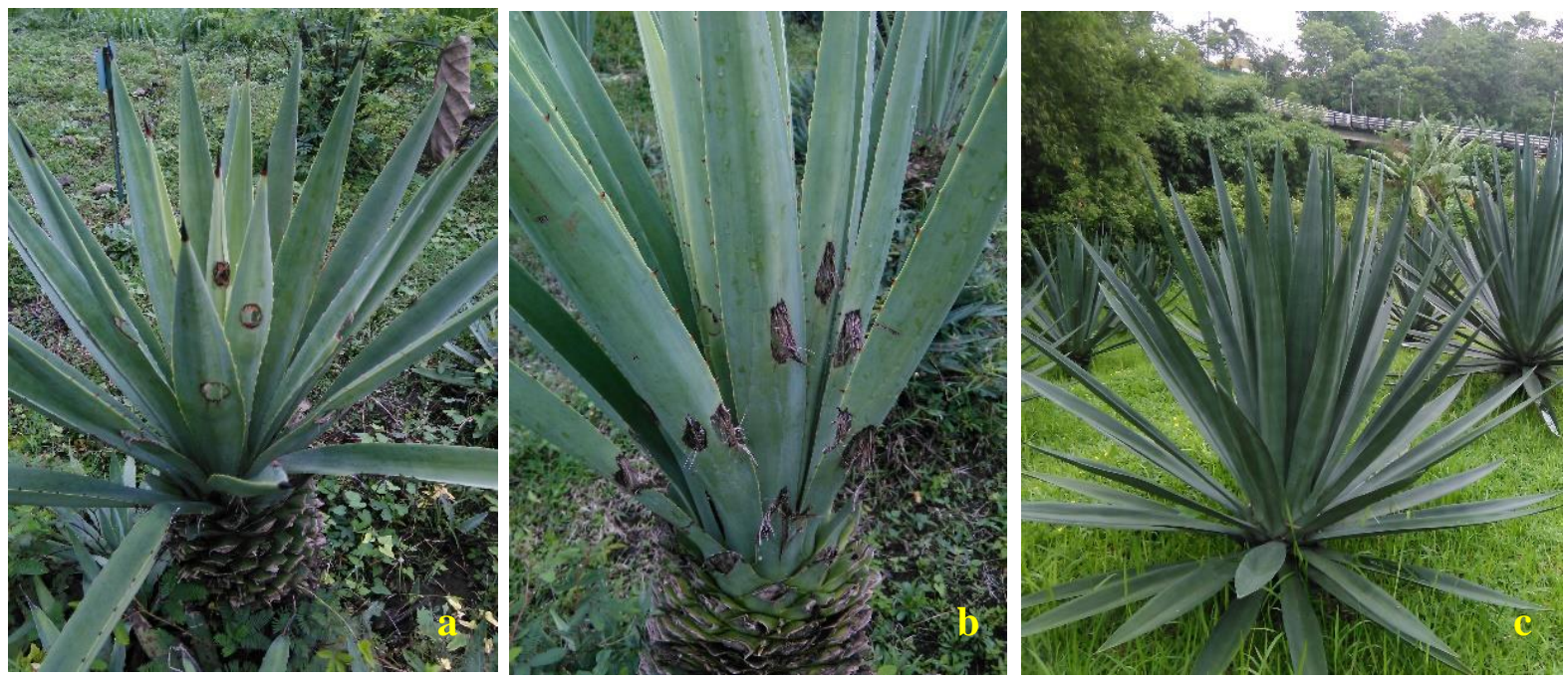

Figure 1 ( $a, b)$ Agave plant with rhinoceros beetle infestation, (c) healthy plant or uninfested plant by rhinoceros beetles 


\section{RESULTS AND DISCUSSION}

\subsection{Identification of Rhinoceros Beetles Infesting Agave spp.}

Rhinoceros beetle infestation in the agave crop occurred from October to December 2016, which is the beginning of the rainy season. The beetle feeds on the unopened leaves of the agave by boring to reach the stem and then sucking the sap of the stem. After the leaf is completely open, a hole about $3 \mathrm{~cm}$ in diameter will be seen, which is a typical symptom of rhinoceros beetle infestation on the plant. The boring movement that reaches the growing point will cause the plant to die. Leaf damage caused by this beetle will cause leaf fibers to break and reduce the quality of the fiber. Leaf damage due to rhinoceros beetle infestation caused the fiber yield to decrease by $17.4 \%$ [16]. The main host plant of $O$. rhinoceros is coconut, but host plants other than coconut, such as sugar cane, pineapple, colocasia, sisal and some Agave species are also infested by these beetles in case there is scarcity of the preferred host [18-20].

Morphological characters of rhinoceros beetle which infested Agave spp. in Karangploso Research Station are as follows: length $35.01 \mathrm{~mm}$; width $14.7 \mathrm{~mm}$; black color (Figure 2a); with scarab-like overall shape; antenna type: lamellate; mandibles visible dorsally (Figure 2b); pygidium exposed (Figure 2c); and two spurs on mesotibia (Figure 2d). Based on its morphological character, rhinoceros beetles which infested $A$. angustifolia, $A$. cantala, and A. sisalana were identified as Oryctes sp. [21]. Kalshoven [15] reported that rhinoceros beetles which infested A. sisalana in Indonesia is Oryctes rhinoceros. The morphological characters of $O$. rhinoceros which was described by Royals et al. [17] are in accordance with the morphological characters of the rhinoceros beetles found infesting Agave spp. The characteristics are as follows: robust body, 22-77 $\mathrm{mm}$ long
(Figure 2e); mandibles often visible dorsally (Figure 2f); pygidium exposed past apex of elytra (Figure 2g); two spurs present on mesotibia (Figure 2h); and claws of meso and metatarsus simple and similar in length and shape.

\subsection{Intensuty of Agave Leaf Damage by Rhinoceros Beetles}

Number of Agave spp. accessions that showed symptoms of rhinoceros beetles infestation was 4 accessions of $A$. angustifolia (80\%), 7 accessions of A.cantala (54\%), and 4 accessions of A. sisalana (67\%). The mean percentage of leaf damage intensity in infested A. angustifolia accessions was relatively higher (16.0 \pm $6.5)$ than those in A. cantala $(6.8 \pm 3.4)$ and A. sisalana $(7.2 \pm 3.8)$ (Table 2). The area of infestation in infested plots indicates that rhinoceros beetles have a relatively higher preference for accessions from $A$. angustifolia compared to accessions from A. cantala and A. sisalana.

The average intensity of leaf damage by rhinoceros beetles in infested accessions of the three Agave species showed a high variation of standard deviation (SD) (Table 2 ), and so did the area of infestation (Table 3). This indicates that the beetles showed a significant preference for only a few accessions from the three host plant species. The beetle preference for certain accessions is probably due to the nutritional content of the host plant.

Based on the identification, the rhinoceros beetle that infested agave plantations in Karangploso was Oryctes rhinoceros (Figure 2). The behaviour of this beetle in consuming its host plant (coconut) is by boring into the central cluster of unopened fronds (the spear cluster) at the centre of the palm crown and boring through the axils of the opened fronds and feeds on the tissue juice of the spears, spathes, inflorescences, and sometimes even the central growing points of the host [22]. Plant sap from several agave species contain sugar [23]. A. angustifolia is one of the Agave species that has high sugar content, so it
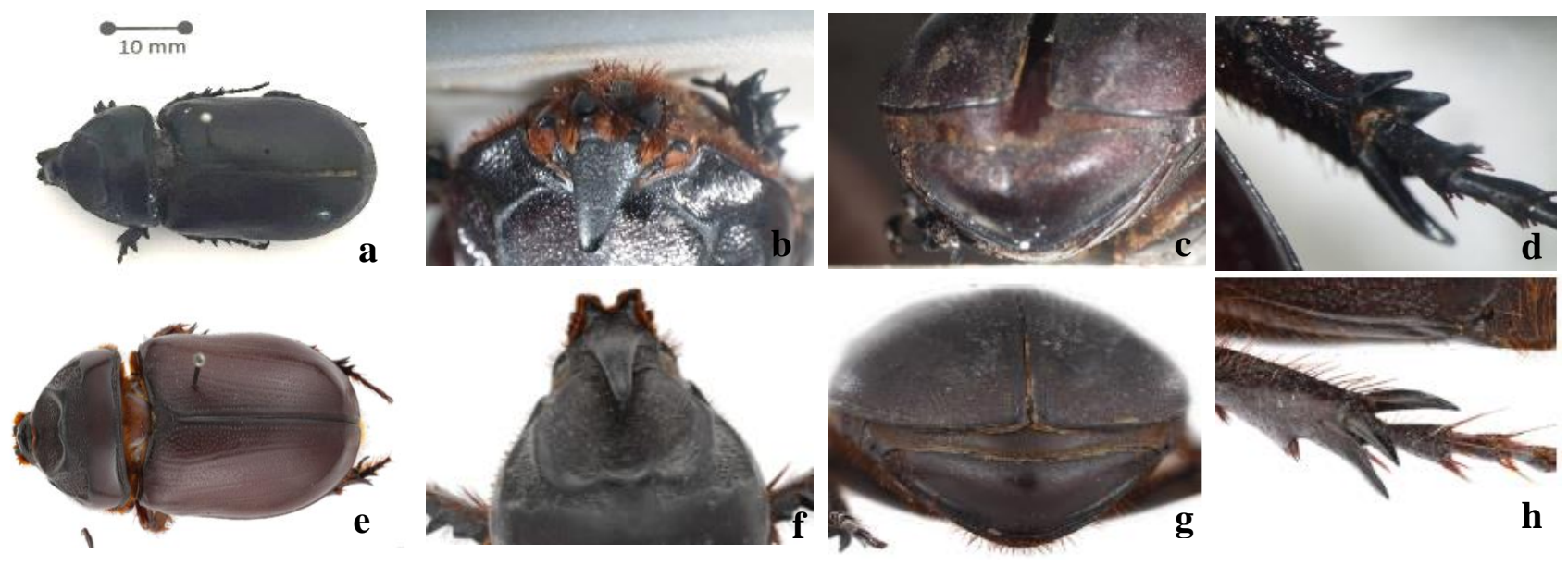

Figure 2 Screening characters for Oryctes spp. beetle based on Redcliffe [18]: (a-d). Identified specimen of Rhinoceros beetle infested Agave spp. in Research Station Karangploso, Malang, (e-h) characters of O. rhinoceros based on Royals et al. [17] 
Table 2 Intensity of Agave Leaf Damage by Rhinoceros Beetles at Karangloso Research Station, Malang on December 2016

\begin{tabular}{|c|c|c|c|c|c|c|}
\hline \multicolumn{4}{|c|}{ Intensity of leaf damage (\%) } & \multicolumn{3}{c|}{ Damage intensity of infested accessions (\%) } \\
\hline A. angustifolia & A. sisalana & A. cantala & A. angustifolia & A. sisalana & A. cantala \\
\hline 21.0 & 2.6 & 9.7 & 0.0 & 21.0 & 2.6 & 9.7 \\
\hline 21.6 & 11.0 & 0.0 & 0.0 & 21.6 & 11.0 & 10.3 \\
\hline 3.9 & 7.8 & 10.3 & 0.0 & 13.9 & 7.8 & 2.4 \\
\hline 7.7 & 2.4 & 2.4 & 0.0 & 7.7 & 2.4 & 3.5 \\
\hline 0.0 & 9.8 & 3.5 & 0.0 & & 9.8 & 4.0 \\
\hline & 0.0 & 4.0 & 0.0 & & & 9.4 \\
\hline
\end{tabular}

${ }^{*}$ Average \pm Standard deviation

Table 3 Infestation area of rhinoceros beetles on accessions of Agave spp. plots at Karangloso Research Station, Malang on December 2016

\begin{tabular}{|c|c|c|c|c|c|c|}
\hline \multicolumn{4}{|c|}{$\begin{array}{c}\text { Pest Incidence (\%) of rhinoceros beetles on Agave spp. } \\
\text { plots }\end{array}$} & \multicolumn{3}{|c|}{$\begin{array}{c}\text { Pest Incidence (\%) of rhinoceros beetles on } \\
\text { infested plots }\end{array}$} \\
\hline A. angustifolia & A. sisalana & \multicolumn{2}{|c|}{ A. cantala } & A. angustifolia & A. sisalana & A. cantala \\
\hline 66.7 & 16.7 & 50.0 & 0.0 & 66.7 & 16.7 & 50.0 \\
\hline 50.0 & 66.7 & 66.7 & 0.0 & 50.0 & 66.7 & 66.7 \\
\hline 16.7 & 16.7 & 16.7 & 0.0 & 16.7 & 16.7 & 16.7 \\
\hline 66.7 & 16.7 & 16.7 & 0.0 & 66.7 & 16.7 & 16.7 \\
\hline \multirow[t]{3}{*}{0.0} & 33.3 & 16.7 & 0.0 & & 33.3 & 16.7 \\
\hline & 0.0 & 33.3 & 0.0 & & & 33.3 \\
\hline & 0.0 & 0.0 & 50.0 & & & 50.0 \\
\hline $40.0 \pm 30.3^{*}$ & $21.4 \pm 23.0$ & \multicolumn{2}{|c|}{$17.9 \pm 23.1$} & $50.0 \pm 23.6$ & $30.0 \pm 21.7$ & $35.7 \pm 20.2$ \\
\hline
\end{tabular}

* Average \pm Standard deviation

is used for traditional bacanora alcoholic drinks [24]. This is thought to be the cause of higher rhinoceros beetle preference for accessions of $A$. angustifolia compared to accessions of $A$. cantala and $A$. sisalana.

In the cultivation of Agave spp., A. angustifolia is cultivated for the stem of the flower (pine), which is processed into alcoholic beverages, while A. cantala and A. sisalana are harvested for their leaves which are extracted to obtained fiber. Fiber content in the leaves of each Agave spp. accession most probably varies, so the chemical compounds in agave fibers which consist of $\alpha$ cellulose, hemicellulose, and lignin, are also different. The differences in chemical components of fiber is thought to affect the preference of rhinoceros beetles to the accessions of the three Agave species.

The sap of Agave species is also reported to have active compounds that are toxic to insects [25]. These toxic compounds, for example saponins, are believed to play a role in plant defence mechanism against phytophagous insects [24, 26]. Harmata et al. [25] reported that saponins extracted form agave act as deterrent to feeding activity. To be able to explain differences in preferences, which are indicated by symptoms of leaf damage due to rhinoceros beetles, data records of quantitative and qualitative saponin level on infested Agave spp. accessions, from each Agave spp accession are needed.

\section{CONCLUSION}

Rhinoceros beetle that infested Agave spp. in ISFCRI/ Balittas germplasm collection was from the genus Oryctes. The Oryctes beetle shows a relatively high preference for accessions of $A$. angustifolia compared to the accessions of A. cantala and A. sisalana. The high preference on $A$. angustifolia is presumably due to the high sugar content in plant stems (pina), which is the consumption target of rhinoceros beetles infesting agave plantations. Future research relating to the breeding of new high-yielding varieties that are resistance to rhinoceros beetle need to 
conacyt.gob.mx/FondosSectoriales/SAGARPA/2011 15/De (2011). [accessed on 8 September 2019]

as parentals.

\section{ACKNOWLEDGMENT}

The author would like to thank Parnidi, MP, who shared information about the rhinoceros Beetle infestation at the Balittas agave germplasm collection.

\section{REFERENCES}

[1] D.A. Hackman, N. Giese, J.S. Markowitz, A. McLean, S.G. Ottariano, C. Tonelli, W. Weissner, S. Welch, C. Ulbricht. Agave (Agave americana): An evidence-based systematic review by the natural standard research Collaboration. J. Herb. Pharmacother. 6 (2006) 101-122. DOI: https://doi.org/10.1080/J157v06n02_09

[2] N.Y. Nava-Cruz, M.A. Medina-Morales, J.L., Martinez, R. Rodriguez, C.N. Aguilar. Agave biotechnology: an overview. Crit. Rev. Biotechnol. (2014) 546-559. DOI: https://doi.org/10.3109/07388551.2014.92 38131-14

[3] L. Santos-Zea, A. Maria Leal-Diaz, E., CortesCeballos, J. Alejandra Gutierrez-Uribe. Agave (Agave spp.) and its traditional products as a source of bioactive compounds. Curr. Bioact. Compd. 8 (2012) 218-231. DOI: https://doi.org/10.2174/157340712802762410

[4] M.I. Garcia-Vieyra, A. Del Real, M.G. Lopez. Agave fructans: their effect on mineral absorption and bone mineral content. J. Med. Food 17 (2014) 1247-1255. DOI: https://doi.org/10.1089/jmf.2013.0137

[5] E. Mellado-Mojica, M.G. Lopez. Identification, classification, and discrimination of agave syrups from natural sweeteners by infrared spectroscopy and HPAEC-PAD. Food Chem. 167 (2015) 349-357. DOI:

https://doi.org/10.1016/j.foodchem.2014.06.111

[6] L. Xiong, M. Maki, Z. Guo, C. Mao, W. Qin. Agave biomass is excellent for production of bioethanol and xylitol using Bacillus strain 65S3 and Pseudomonas strain CDS3. J. Biobased Mater. Bio. 8 (2014) $422-$ 428. DOI: https://doi.org/10.1166/jbmb.2014.1453

[7] R.J. Stewart. Agave as a Model CAM Crop for a Warming and Drying World, Front. Plant Sci. 6 (2015) 684. www.frontiersin.org

[8] G. Paz J Del Bosque. Demandas del sector 2011-15. Fondo sectorial de Investigación en Materia Agrícola, Pecuarı'a, Acuacultura, Agrobioecnologi'a y Recursos Fitogene'ticos. Available from: 20062012
[9] D.L. Lindsay, P. Bailey, R.F. Lance, M.J. Clifford, R. Delph, \& N.S. Cobb. Effects of a nonnative, invasive lovegrass on Agave palmeri distribution, abundance, and insect pollinator communities. Biodivers. Conserv. 20 (13) (2011) 3251-3266. DOI: 10.1007/s10531-011-0133-x)

[10] G. Lugo-García. L.D. Ortega-Arenas, H. GonzálezHernández, A. Aragón-García, J. Romero-Nápoles, R. Rubio-Cortés, \& M.A. Morón. Melolonthidae nocturnos (Coleoptera) recolectados en la zona agrícola agavera de Jalisco, México. Acta Zoológica Mexicana, New Series, 27 (2), (2011) 341-357

[11] C. Deloya, J. Ponce, H. Gasca, G. Aguirre. \& M.C. Zamora. Familia Scarabaeidae Latreille, 1802. In: Deloya, C., Ponce, J., Reyes, P., Aguirre, G. (Eds.), Escarabajos del Estado de Michoacán (Coleoptera: Scarabaeioidea). México. Universidad Michoacana de San Nicolás de Hidalgo, Morelia, Michoacán 2016, pp. 93-142

[12] M.M. Villada. Sección de Zoología. La Naturaleza, Segunda Serie III, (1903) 21-24

[13] E.J. Quiroz, O.M. Morales \& O.T. Ramírez. Primera intercepción del escarabajo rinoceronte asiático del cocotero Oryctes rhinoceros (Linnaeus, 1758) en México. Revista Mexicana de Ciencias Forestales 8 (39, (2017) 99-105

[14] R.M. Giblin-Davis, Insects on palms. Edited by FW Howard, D. Moore, RM. Giblin-Davis, RG. Abad. CABI Publishing, Wallingford, GB, (2001) pp. $267-$ 304.

[15] L. GE. Kalshoven. Pest of crop in Indonesia. Revised and Translated by van der Laan. P.A. Jakarta. PT. Ichtiar Baru van Hoeve (1981) 842p

[16] Parnidi. Pcnurunan Potcnsi Produksi Scrat Agave Akibat Kumbang Penggerek Pucuk (Oryctes rhinoceros). Info. Tek. Perkebunan, 8(5) (2016) 19

[17] H. R. Royals, T. M. Gilligan and C. F. Brodel. Coconut Rhinoceros Beetles, Oryctes spp. (2012). https://caps.ceris.purdue.edu/taxonomic-services

[18] T. B. Fletcher. Some South Indian insects and other Animals of Economic Importance. Agricultural Research Institute, New Delhi, 1914, 565p

[19] C. C. Ghosh, Oryctes rhinoceros and other important Palm Pests in Burma. Report of Proceedings. 5th Entomology. Meeting, Pusa, 1924, pp. 99-103

[20] J. L. Gressitt. The Coconut Rhinoceros Beetle (Oryctes rhinoceros) with particular Reference to the Palau Islands. Bull. Bishop Mus. 212 (1953) 157

[21] B. C. Ratcliffe, and R. D. Cave. The Dynastinae (Coleoptera: Scarabaeidae) of the Bahamas with a 
[25] J. Harmata, B. Mauchamp, C. Arnault, and L. Salama. Identification of spirostane type saponin in the flowers of leek with inhibitory effect on growth of leek mouth larvae. Biochem. System. Ecol. 15 (1) (1987) 113-116. DOI:https://doi.org/10.1016/03051978(87)90089-5

[26] M. Debnath, M. Pandey, R. Sharma, G. S. Thakur, and P. Lal. Biotechnological intervention of Agave sisalana: A unique fiber yielding plant with medicinal property. Journal of Medicinal Plants Research 4 (3) (2010) 177-187. Available online at www.academic journals.org/JMPRISSN1996$0875 \odot 2010$ distinct taxa. Brittonia, 55 (2003) 82-87. DOI: https:// doi.org/10.1663/0007utilization in animal feeding Cuban Journal of Agricultural Science 43 (2009) 169

[24] A. García-Mendoza. \& F. Chiang. The confusion of Agave vivipara L. and A. angustifolia Haw., two

Great Inagua Island. Insecta Mundi, 24 (2010) 1-10 309-339. DOI:

[23] Y. García-Curbelo, G. M. López. \& R. Bocourt. 